\title{
Performance of Different Groundnut (Arachis hypogaea L.) based Intercropping Systems with Millets under Rainfed Condition of Odisha
}

\author{
S. Lenka, S.K. Swain, K.C. Pradhan
}

10.18805/LR-4690

\begin{abstract}
Background: Groundnut as a sole crop is affected by adverse weather conditions coupled with damage by insect, pest and disease, results in economic losses and in extreme cases complete failure of the crop. Intercropping is one of the important cropping systems recommended to mitigate the aberrant climatic conditions with an aim to increase total productivity per unit area. The present study was done to assess the effect of different millet based intercropping system on growth and yield of groundnut under rainfed condition. Methods: A field experiment was conducted during kharif 2018 and 2019 at Agricultural Research Farm of All India Coordinated Research Project on Groundnut, OUAT, Bhubaneswar on mixed red and black medium soil. The experiment was laid out in randomized complete block design and replicated thrice. It consisted of ten treatments comprising of groundnut with three millets viz., finger millet, little millet and foxtail millet. Millets were intercropped with groundnut in the replacement series of 4:2 and 2:1 row proportion along with mono-cropped millets and groundnut.

Result: Significantly higher no. branches/plant (5.2), leaflet/no. plant (79.33) and dry matter accumulation (25.77g/plant) was recorded in groundnut + finger millet (2:1) whereas, sole groundnut incurred significantly higher pod no/plant (16.5), 100 kernel weight (37.2g), shelling\% (77.8), pod yield $(1736 \mathrm{~kg} / \mathrm{ha})$ and haulm yield $(3613 \mathrm{~kg} / \mathrm{ha})$ over all other intercropping systems. Further, groundnut pod equivalent yield (GPEY), land equivalent ratio (LER), area time equivalent ratio (ATER) and economics were higher in 2:1 row ratio of groundnut + finger millet compared to any of the sole and intercropping systems. The competition ratio and aggressivity of little millet was greater than that of other millets. So, it was most dominant crop over groundnut compared to other millets in the intercropping systems.
\end{abstract}

Key words: Aggressivity, Competition ratio, Groundnut, Groundnut pod equivalent yield, Intercropping, Millet, Relative crowding coefficient.

\section{INTRODUCTION}

Intercropping is growing of two or more crops simultaneously in the same piece of land and popular in rain-fed agriculture with limited resources, because both the crops complement each other in exploiting resources. The main advantage of intercropping is yield stability over mono-cropping, which is reliable food and feed production over the years. The important reason for intercropping legumes with nonlegumes is that legumes can fix atmospheric nitrogen which may be available to the associated non-legumes (Senaratne et al., 1994) and it is a common practice during the rainy season in the semi-arid tropics of India. It also helps in reduction of insects and pests in main crop.

Groundnut (Arachis hypogaea L.) is a leading oilseed crop in India. The kernels are rich source of edible oil (43$55 \%)$ and protein (25-28\%), also a valuable source of vitamins viz., E, K and B (Kandakoor et al., 2014). The crop is also called "king of oilseeds" and poor man's almond. In India the groundnut is grown in an area of about 5.34 million hectare, producing 7.5 million tons with a productivity of 1445 $\mathrm{kg} / \mathrm{ha}$ (Annual Report, Ministry of Agriculture and Farmers' Welfare, 2016-17) and contributes to $55 \%$ of the total oil seed production in the country.

Millets are adapted to a wide range of ecological conditions, play an important role in rainfed region of the
All India Co-ordinated Research Project on Groundnut, Orissa University of Agriculture and Technology, Bhubaneswar-751 003, Orissa, India.

Corresponding Author: S. Lenka, All India Co-ordinated Research Project on Groundnut, Orissa University of Agriculture and Technology, Bhubaneswar-751 003, Orissa, India.

Email: subhrasini@gmail.com

How to cite this article: Lenka, S., Swain, S.K., Pradhan, K.C. (2021). Performance of Different Groundnut (Arachis hypogaea L.) based Intercropping Systems with Millets under Rainfed Condition of Odisha. Legume Research. DOI: 10.18805/LR-4690.

Submitted: 08-06-2021 Accepted: 11-10-2021 Online: 16-11-2021

country and are often grown on nutrient poor soils. The minor millets are rich source of nutrients and minerals and resistant to drought and stress in rainfed farming. So they are considered as nutria-cereals and are a source of food, feed and fodder. In India, small millets are being cultivated in an area of 1.79 million hectare producing 2.21 million tones with productivity of $1601 \mathrm{~kg} / \mathrm{ha}(2015-16)$ [Annual Progress Report, ICAR-AICRP on Small Millets, (2017-18) Bengaluru]. In Odisha, minor millets are cultivated with an area of 25.4 thousand hectare producing 12.7 thousand tones of grains 
with productivity of $501 \mathrm{~kg} / \mathrm{ha}$ (Orissa Agriculture Statistics, 2015-16).

Millets are hardy, resilient and short duration crops, grown in diverse agro-climatic areas under adverse climatic condition and it can be one of the best options for a viable and practicable intercropping system with groundnut (Shwethanjali et al., 2018). Therefore, the present study was undertaken for two years on intercropping of groundnut and millets to study the effect of different millet based intercropping system on growth and yield of groundnut under rainfed condition.

\section{MATERIALS AND METHODS}

A field experiment was conducted during kharif 2018 and 2019 at Research farm of All India Coordinated Research Project on Groundnut, Bhubaneswar, Khurda District, Odisha, to study the performance of groundnut (Arachis hypogaea L.) in different millet based intercropping systems under rainfed conditions. The experiment was carried out in a randomized complete block design and each treatment was replicated thrice. The soil of the experimental plot was uniformly leveled and well drained. It was sandy loam in texture, low in organic carbon content $(0.35 \%)$, medium in available nitrogen (389 kg/ha) and phosphorus (17 kg/ha), low in available potassium ( $82 \mathrm{~kg} / \mathrm{ha}$ ) and slightly acidic in reaction $(\mathrm{pH} 5.49)$. The crop received rainfall of $1121.4 \mathrm{~mm}$ in 50 rainy days and $1207 \mathrm{~mm}$ in 62 rainy days during the crop growth period in kharif 2018 and 2019, respectively. The mean maximum and minimum temperature were $32.4^{\circ} \mathrm{C}$ and $23.8^{\circ} \mathrm{C}$ in 2018 and $32.5^{\circ} \mathrm{C}$ and $25.5^{\circ} \mathrm{C}$ in 2019 , respectively during the crop growth period. The millets assessed in the intercropping systems are finger millet (Eleusine coracana L.) foxtail millet (Setaria italica L.) and little millet (Panicum sumatrens L.) in 4:2 and 2:1row proportions. The treatments included in the experiment were $\mathrm{T}_{1}$ : Sole groundnut, $\mathrm{T}_{2}$ : Sole little millet, $\mathrm{T}_{3}$ : Sole finger millet, $\mathrm{T}_{4}$ : Sole foxtail millet, $\mathrm{T}_{5}$ : Groundnut + little millet $(4: 2), \mathrm{T}_{6}$ : Groundnut + little millet $(2: 1), \mathrm{T}_{7}$ : Groundnut + finger millet (4:2), $\mathrm{T}_{8}$ : Groundnut + finger millet (2:1), $\mathrm{T}_{9}$ : Groundnut + foxtail millet $(4: 2)$ and $T_{10}$ : Groundnut + foxtail millet $(2: 1)$. The varieties tested in this experiment were Dharani (Groundnut), Arjuna (Finger millet), OLM-217 (Little millet) and DHFt-109-3 (Foxtail millet). Groundnut and all the three millets were sown at $30 \mathrm{~cm} \times 10 \mathrm{~cm}$ both in sole crop and intercropping system. Under intercropping systems with 4:2 row proportion, 2 rows of millet was sown after each 4 rows of groundnut and in 2:1 row proportion, 1 row of millet was sown after each 2 rows of groundnut. For groundnut, nutrients were applied @ 20:40:40 kg/ha N, $\mathrm{P}_{2} \mathrm{O}_{5}, \mathrm{~K}_{2} \mathrm{O}$ in the form of urea, SSP and MOP, respectively along with $5 \mathrm{t}$ of farm yard manure. Gypsum was applied @ 500 kg/ ha in 2 equal splits i.e. at time of sowing and during the time of earthing up. For millets, the recommended dose of $60 \mathrm{~kg} \mathrm{~N}$, $30 \mathrm{~kg} \mathrm{P}_{2} \mathrm{O} 5$ and $30 \mathrm{~kg} \mathrm{~K} \mathrm{~K}_{2} \mathrm{O} / \mathrm{ha}$ was applied through urea, SSP and MOP for finger millet, $40 \mathrm{~kg} \mathrm{~N}, 20 \mathrm{~kg} \mathrm{P} \mathrm{O}_{5} \mathrm{~kg} / \mathrm{ha}$ for little millet and $40 \mathrm{~kg} \mathrm{~N}, 20 \mathrm{~kg} \mathrm{P}_{2} \mathrm{O}_{5} 20 \mathrm{~K}_{2} \mathrm{O} \mathrm{kg} / \mathrm{ha}$ for foxtail millet, respectively.

Ten plants were tagged for recording plant height and branch number at different stages of crop. Five randomly selected plants were used to record the dry matter production at different stages of groundnut. The plants were uprooted and oven dried separately at $70^{\circ} \mathrm{C}$ for 48 hours and the dry weight (g/plant) was recorded.

Groundnut pod equivalent yield (GPEY) of intercropping system was calculated by taking into account the pod yield of component crops and the prevailing market price of both millets and groundnut expressed in terms of $\mathrm{kg} /$ hectare. Using different formulae proposed by many researchers, Intercropping efficiencies were deduced from measured yield.

\section{Groundnut pod equivalent yield (GPEY)}

$$
\begin{aligned}
& \text { GPEY }(\mathrm{kg} / \mathrm{ha})=\begin{array}{r}
\text { Yield of groundnut in intercropping } \\
\text { system }(\mathrm{kg} / \mathrm{ha})
\end{array} \\
& +\frac{\text { Yield of millet }(\mathrm{kg} / \mathrm{ha}) \times \text { Market price of millet }(\mathrm{Rs} / \mathrm{ha})}{\text { Market price of groundnut }(\mathrm{Rs} / \mathrm{ha})}
\end{aligned}
$$

\section{Land equivalent ratio}

Land equivalent ratio (LER) was worked out by using the formula of Willey (1979).

LER $=$ LER groundnut $+\mathrm{L}$ millet $=(Y s g / Y i g)+(Y s m / Y i m)$

Where,

Ysm = Yield of sole millet.

Yim = Yield of intercrop millet.

Ysg = Yield of sole groundnut.

Yig = Yield of intercrop groundnut.

\section{Area time equivalent ratio}

ATER provides more realistic comparison of the yield advantage of intercropping over mono-cropping in terms of time taken by component crops in the intercropping systems (Hiebsch and McCollum 1987). ATER was calculated using the following formula:

$$
\begin{gathered}
\text { ATER }=(\text { ATER groundnut }+ \text { ATER millet }) \\
\text { ATER groundnut }=(Y \text { ig } / Y s g) \times(T g / T i) \\
\text { ATER millet }=(Y \text { Ym } / Y s m) \times(T m / T i)
\end{gathered}
$$

Where,

$\mathrm{Tg}$ = Duration of growth cycle of groundnut

$\mathrm{Tm}=$ Duration of growth cycle millet

$\mathrm{Ti}=$ Duration in days of the species with the longest growing period.

\section{Aggressivity}

Aggressivity as proposed by Gilchrist (1965) and competitive ratio by Willey and Rao (1980) were two indices used to determine the intercrops competition.

Aggressivity of millet $=$

$$
[\mathrm{Ym} \div(\mathrm{Ysm} \times \mathrm{Zm})]-[\mathrm{Yig} \div(\mathrm{Ysg} \times \mathrm{Zg})]
$$

Aggressivity of groundnut $=$

$$
[\mathrm{Yg} \div(\mathrm{Ysg} \times \mathrm{Zg})]-[\mathrm{Yim} \div(\mathrm{Ysm} \times \mathrm{Zm})]
$$


Where:

$\mathrm{Zm}=$ Proportion of millet in intercrop.

$\mathrm{Zg}=$ Proportion of groundnut in intercrop.

\section{Competition ratio}

Competition ratio of groundnut $=$

(LER groundnut/LER millet) $\times(\mathrm{Zm} / \mathrm{Zg})$

Competition ratio of millet $=$

$($ LER millet/LER groundnut $) \times(Z g / Z m)$

\section{Relative crowding coefficient}

De Wit (1960) introduced the relative crowding coefficient (RCC or K) in plant competition theory. The K was calculated as.

$\mathrm{K}=\mathrm{K}$ groundnut $\times \mathrm{K}$ millet

$\mathrm{K}$ groundnut $=(\mathrm{Yig} \times \mathrm{Zm}) /[(\mathrm{Ysg}-\mathrm{Yig}) \times \mathrm{Zg}]$

$\mathrm{K}$ millet $=(\mathrm{Yim} \times \mathrm{Zg}) /[(\mathrm{Ysm}-\mathrm{Yim}) \times \mathrm{Zm}]$

Data collected for various studies were subjected to the analysis of variance (ANOVA) appropriate to the design as given by Gomez and Gomez (1984). The significant differences between treatments were compared with the critical difference at $5 \%$ level of probability.

\section{RESULTS AND DISCUSSION}

\section{Effect of different intercropping systems on growth attributes of groundnut}

Several growth parameters of groundnut such as plant height, branch no., leaflets/plant and dry matter accumulation/plant varied significantly in different sole and intercropping treatments. Data presented in Table 1 revealed that, among various treatments, higher plant height $(65.2 \mathrm{~cm})$ and branch no./plant (5.2) was recorded in intercropping of groundnut + finger millet with 2:1 row proportion followed by sole groundnut $(63.6 \mathrm{~cm})$. Similarly, it also recorded significantly higher dry matter accumulation/plant $(25.77 \mathrm{~g})$ followed by sole groundnut (23.24), which was at par with groundnut + finger millet with 4:2 row proportion. This could be due to proper utilization and distribution of different resources i.e. light, water and nutrients between the rows of groundnut

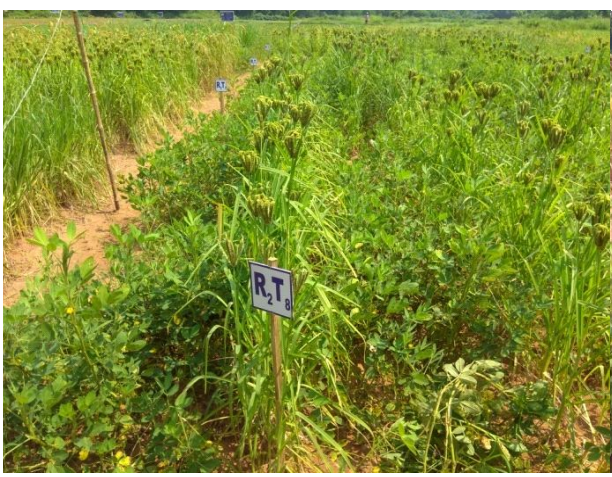

\section{Groundnut + Finger millet (2:1)}

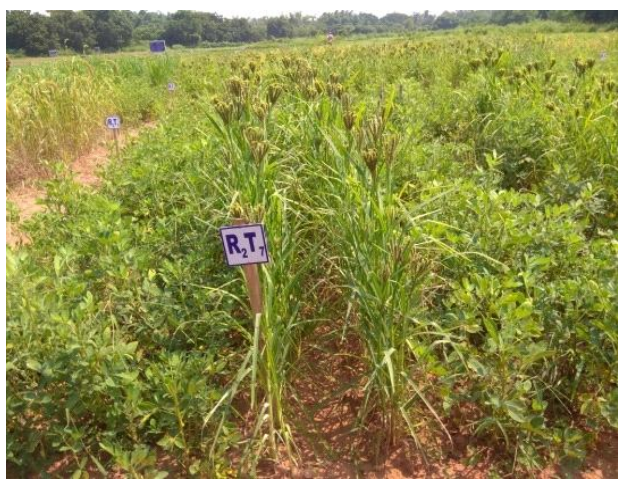

Groundnut + Finger millet $(4: 2)$

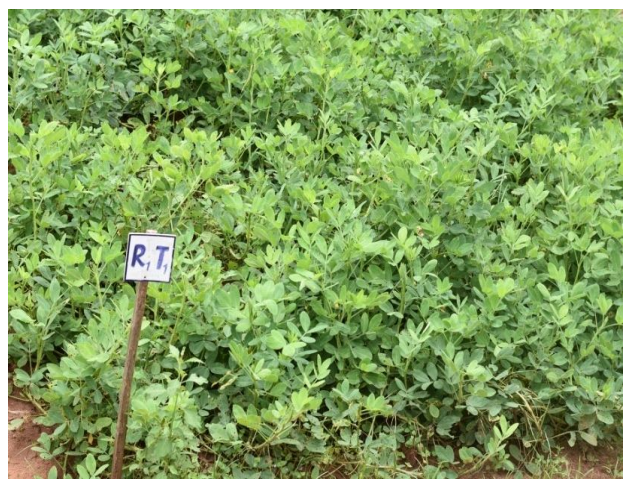

Sole groundnut

Table 1: Growth parameters of groundnut as influenced by groundnut-based millets intercropping system (Pooled data of 2 years).

\begin{tabular}{|c|c|c|c|c|}
\hline Treatment & $\begin{array}{l}\text { Plant height } \\
(\mathrm{cm})\end{array}$ & $\begin{array}{c}\text { Branch } \\
\text { no./plant }\end{array}$ & $\begin{array}{l}\text { No. of leaf } \\
\text { lets/plant }\end{array}$ & $\begin{array}{c}\text { Dry matter accumulation } \\
\text { (g/plant) }\end{array}$ \\
\hline$T_{1}:$ Sole groundnut & 65.2 & 4.8 & 67.11 & 23.24 \\
\hline $\mathrm{T}_{2}:$ Sole little millet & - & - & - & - \\
\hline $\mathrm{T}_{3}$ : Sole finger millet & - & - & - & - \\
\hline $\mathrm{T}_{4}:$ Sole fox tail millet & - & - & - & - \\
\hline $\mathrm{T}_{5}:$ Groundnut + Little millet $(4: 2)$ & 60.9 & 4.5 & 71.70 & 21.56 \\
\hline $\mathrm{T}_{6}:$ Groundnut + Little millet $(2: 1)$ & 60.2 & 4.6 & 78.32 & 22.41 \\
\hline $\mathrm{T}_{7}:$ Groundnut + Finger millet $(4: 2)$ & 63.6 & 4.8 & 76.36 & 23.04 \\
\hline $\mathrm{T}_{8}:$ Groundnut + Finger millet $(2: 1)$ & 59.6 & 5.2 & 79.33 & 25.77 \\
\hline $\mathrm{T}_{9}:$ Groundnut + Fox tail millet $(4: 2)$ & 62.9 & 4.3 & 70.40 & 20.07 \\
\hline $\mathrm{T}_{10}:$ Groundnut + Fox tail millet $(2: 1)$ & 62.0 & 4.7 & 64.12 & 21.81 \\
\hline $\operatorname{SEm}( \pm)$ & 3.08 & 0.27 & 2.39 & 1.14 \\
\hline$C D(p=0.05)$ & NS & 0.82 & 7.36 & 3.79 \\
\hline
\end{tabular}


and decreased competition for same resources. These results were in accordance with the findings of Shwethanjali et al. (2018), Maitra et al. (2001) and Shiva Kumar and Yadahalli (1996).

\section{Effect of different intercropping systems on yield and yield attributing characters of groundnut}

Among various treatments, significantly higher no. of pod/ plant of groundnut was recorded in sole crop of groundnut (16.5) and shelling\% (77.8\%) compared to any intercropping systems. Among the intercropping systems, higher pod/plant (15.6) and shelling\% (78\%) of groundnut was recorded in groundnut + finger millet 2:1 row proportion which was at par with groundnut + finger millet 4:2 row ratio (Table 2).

Significantly higher groundnut pod yield $(1736 \mathrm{~kg} / \mathrm{ha})$ and haulm yield $(3613 \mathrm{~kg} / \mathrm{ha})$ were recorded in sole groundnut. Comparing different intercropping systems, groundnut + finger millet with 2:1 row ratio incurred higher groundnut pod (1262 kg/ha) and haulm yield $(2714 \mathrm{~kg} / \mathrm{ha})$. Cropping system significantly influence groundnut population and the highest groundnut population was recorded in sole groundnut. This could be due to higher plant population and competition free environment in sole crop as compared to intercropped groundnut. Similar results were in tune with Shalim Uddin et al. (2003) and Berhanu et al. (2016).

\section{Effect of different intercropping on yield advantages and economics of groundnut}

The statistical analysis of data in Table 3 indicated that significantly higher groundnut pod equivalent yield (GPEY) of $1754 \mathrm{~kg} / \mathrm{ha}$ was recorded in the groundnut + finger millet (2:1) association, which was statistically at parallel with sole groundnut $(1745 \mathrm{~kg} / \mathrm{ha})$ and groundnut + finger millet with 4:2 row proportion. The lowest GPEY was recorded with sole fox tail millet $(451 \mathrm{~kg} / \mathrm{ha})$. Yield advantage in terms of LER was greatest (1.30) in the groundnut + finger millet with 2:1 row ratio followed by intercropping of groundnut + finger millet with $4: 2$ row ratio. The lowest LER (1.08) was recorded in groundnut + little millet $(4: 2)$ association

Table 2: Yield and yield attributing parameters of groundnut as influenced by groundnut-based millets intercropping system (Pooled data of 2 years).

\begin{tabular}{|c|c|c|c|c|}
\hline Treatments & $\begin{array}{l}\text { No. of pods/ } \\
\text { plant }\end{array}$ & $\begin{array}{c}\text { Shelling } \\
(\%)\end{array}$ & $\begin{array}{l}\text { Groundnut pod } \\
\text { yield (kg/ha) }\end{array}$ & $\begin{array}{l}\text { Groundnut haulm } \\
\text { yield (kg/ha) }\end{array}$ \\
\hline$T_{1}$ : Sole groundnut & 16.5 & 77.8 & 1736 & 3613 \\
\hline $\mathrm{T}_{2}$ : Sole little millet & - & - & - & - \\
\hline $\mathrm{T}_{3}:$ Sole finger millet & - & - & - & - \\
\hline $\mathrm{T}_{4}:$ Sole fox tail millet & - & - & - & - \\
\hline $\mathrm{T}_{5}:$ Groundnut + Little millet $(4: 2)$ & 11.6 & 73.9 & 1070 & 2664 \\
\hline $\mathrm{T}_{6}:$ Groundnut + Little millet $(2: 1)$ & 12.3 & 75.3 & 1113 & 2636 \\
\hline $\mathrm{T}_{7}:$ Groundnut + Finger millet $(4: 2)$ & 13.1 & 76.3 & 1221 & 2712 \\
\hline $\mathrm{T}_{8}:$ Groundnut + Finger millet $(2: 1)$ & 15.6 & 77.0 & 1262 & 2714 \\
\hline $\mathrm{T}_{9}:$ Groundnut + Fox tail millet $(4: 2)$ & 10.6 & 75.4 & 1051 & 2603 \\
\hline $\mathrm{T}_{10}:$ Groundnut + Fox tail millet $(2: 1)$ & 11.8 & 74.0 & 1126 & 2707 \\
\hline $\operatorname{SEm}( \pm)$ & 1.15 & 2.01 & 57.0 & 128.9 \\
\hline$C D(p=0.05)$ & 3.54 & NS & 175.6 & 397.3 \\
\hline
\end{tabular}

Table 3: Production and profitability of groundnut + millets intercropping systemin different row proportion intercropping systems (Pooled data of 2 years).

\begin{tabular}{|c|c|c|c|c|c|}
\hline Treatments & GPEY* & LER $^{*}$ & ATER $^{*}$ & $\mathrm{NR}^{*}(\mathrm{Rs})$ & $\mathrm{BCR}^{*}$ \\
\hline $\mathrm{T}_{1}$ : Sole groundnut & 1745 & 1.00 & 1.00 & 40073 & 1.87 \\
\hline $\mathrm{T}_{2}:$ Sole little millet & 604 & 1.00 & 1.00 & 11314 & 1.40 \\
\hline $\mathrm{T}_{3}:$ Sole finger millet & 865 & 1.00 & 1.00 & 21504 & 1.86 \\
\hline $\mathrm{T}_{4}$ : Sole fox tail millet & 451 & 1.00 & 1.00 & 10809 & 1.28 \\
\hline $\mathrm{T}_{5}:$ Groundnut + Little millet $(4: 2)$ & 1378 & 1.08 & 1.04 & 30335 & 1.64 \\
\hline $\mathrm{T}_{6}:$ Groundnut + Little millet $(2: 1)$ & 1437 & 1.25 & 1.13 & 27233 & 1.58 \\
\hline $\mathrm{T}_{7}:$ Groundnut + Finger millet $(4: 2)$ & 1718 & 1.29 & 1.16 & 35715 & 1.76 \\
\hline $\mathrm{T}_{8}:$ Groundnut + Finger millet $(2: 1)$ & 1754 & 1.30 & 1.18 & 41778 & 1.89 \\
\hline $\mathrm{T}_{9}:$ Groundnut + Fox tail millet $(4: 2)$ & 1278 & 1.09 & 1.01 & 17202 & 1.37 \\
\hline $\mathrm{T}_{10}:$ Groundnut + Fox tail millet $(2: 1)$ & 1361 & 1.19 & 1.04 & 22805 & 1.48 \\
\hline $\operatorname{SEm}( \pm)$ & 60.5 & 0.050 & 0.039 & - & - \\
\hline$C D(p=0.05)$ & 179.88 & 0.149 & 0.117 & - & - \\
\hline
\end{tabular}

*GPEY- Groundnut pod equivalent yield, LER- Land equivalent ratio, ATER- Area time equivalent ratio, NR- net return, BCR-Benefit cost ratio. 
Performance of Different Groundnut (Arachis hypogaea L.) based Intercropping Systems with Millets under Rainfed Condition of Odisha

Table 4: Competition ratio $(\mathrm{CR})$, aggressivity and relative crowding coefficient $(\mathrm{RCC})$ of Groundnut and millets under groundnut+millet intercropping system (Pooled data of 2 years).

\begin{tabular}{|c|c|c|c|c|c|}
\hline \multirow{2}{*}{ Treatment } & \multicolumn{2}{|c|}{ Competition ratio } & \multicolumn{2}{|c|}{ Aggressivity } & \multirow{2}{*}{$\mathrm{RCC}$} \\
\hline & CR groundnut & CR millet & Groundnut & Millet & \\
\hline $\mathrm{T}_{1}$ : Sole groundnut & - & - & - & - & - \\
\hline $\mathrm{T}_{2}:$ Sole little millet & - & - & - & - & - \\
\hline $\mathrm{T}_{3}:$ Sole finger millet & - & - & - & - & - \\
\hline $\mathrm{T}_{4}:$ Sole fox tail millet & - & - & - & - & - \\
\hline $\mathrm{T}_{5}:$ Groundnut + Little millet $(4: 2)$ & 0.64 & 1.00 & -0.57 & 0.57 & 1.81 \\
\hline $\mathrm{T}_{6}:$ Groundnut + Little millet $(2: 1)$ & 0.57 & 1.15 & -0.75 & 0.75 & 2.58 \\
\hline $\mathrm{T}_{7}:$ Groundnut + Finger millet $(4: 2)$ & 0.64 & 1.12 & -0.61 & 0.61 & 3.46 \\
\hline $\mathrm{T}_{8}:$ Groundnut + Finger millet $(2: 1)$ & 0.67 & 1.10 & -0.56 & 0.56 & 4.26 \\
\hline $\mathrm{T}_{9}:$ Groundnut + Fox tail millet $(4: 2)$ & 0.60 & 1.03 & -0.63 & 0.63 & 1.91 \\
\hline $\mathrm{T}_{10}:$ Groundnut + Fox tail millet $(2: 1)$ & 0.60 & 1.11 & -0.68 & 0.68 & 2.44 \\
\hline $\operatorname{SEm}( \pm)$ & 0.044 & 0.074 & - & 0.050 & 0.201 \\
\hline$C D(p=0.05)$ & 0.137 & 0.233 & - & 0.158 & 0.632 \\
\hline
\end{tabular}

(Table 3).This corroborated the findings of several researchers (Willey, 1979; Reddy and Willey, 1981).

Significantly higher area time equivalent ratio was recorded in 2:1 row ratios of groundnut + finger millet (1.18). It was on par with 4:2 row ratios of groundnut + finger millet (1.16) and 2:1 row ratio of groundnut + little millet (1.13). The lower area time equivalent ratio was recorded in sole crops (1.0).

Data presented in the Table 3 revealed that net return was higher in2:1 row ratio of groundnut + finger millet (Rs 41778/ha) compared to any intercropping systems followed by sole groundnut (Rs $40073 /$ ha). It also recorded higher $\mathrm{B}: \mathrm{C}$ ratio of 1.89 followed by sole groundnut. The lower net returns and $B: C$ ratio was recorded in sole fox tail millet (Rs 10809/ha). Increased economic returns were attributed by higher market prices of groundnut and finger millet coupled with better utilization of resources.

\section{Effect of different intercropping systems on competition} indices

The competitive ability of groundnut and the three millets in different row proportion was also estimated through aggressivity and rate of competitiveness. The results showed that the variation of aggressivity $(A)$ and competition ratio (CR) depended on the configuration of the intercropping systems (Table 4). The data presented in the Table 4showed that the value of aggressivity of groundnut was negative and it was considered as the less-dominant crop in the system. The positive aggressivity values indicated that among all the millets, little millet was most dominant crop over groundnut followed foxtail millet. This dominance was more pronounced in the association with the groundnut at the row ratio of $2: 1$ in case of little millet $(0.75)$. On the contrary, fox tail millet was more aggressive in the association with groundnut in 4:2 row proportions. The CR value of groundnut was less than those of the associated millets in all the cropping systems tested. The trend observed for the relative crowding coefficient $(\mathrm{K})$ revealed that the association of groundnut with finger millet in 2:1 row proportion (4.26) have more yield advantage followed by $4: 2$ row proportion (3.46) over all other intercropping systems. These results are in tune with the findings of Ghosh et al. (2004).

Regardless of different row ratios, finger millet was more compatible with groundnut than other two millets. The present study on intercropping of groundnut with different millets clearly revealed that association of groundnut + finger millet at 2:1 row proportion is suitable combination for getting higher yield and economic benefit followed by groundnut + finger millet at 4:2 row ratio under rainfed conditions of East and south eastern coastal plains of Odisha.

\section{REFERENCES}

Berhanu, H., Hunduma, A., Degefa, G., Legesse, Z., Abdulselam, F. and Tadese, F. (2016). Determination of Plant Density on Groundnut (Arachis hypogaea L.) intercropped with Sorghum (Sorghum bicolor L.) at Fadis and Erer of Eastern Hararghe. Preprints 2016, 2016100084 (doi: 10.20944/ preprints201610.0084.v1).

De Wit, C.T. (1960). On competition. Verslag Landbouw-Kundige Onderzoek. 66: 1-28.

Ghosh, P.K. (2004). Growth, yield, competition and economics of groundnut/cereal fodder intercropping systems in the semiarid tropics of India. Field Crops Research. 88: 227-237.

Gomez, K.A. and Gomez, A.A. (1984). Statistical Procedure for Agriculture Research, $2^{\text {nd }}$ Ed., John Willey and Sons, New York. 68.

Hiebsch, C.K. and McCollum, R.E. (1987). Area-X-time equivalency ratio; A method for evaluating the productivity of intercrops. Agronomy Journal. 79: 15-22.

Kandakoor, S.B., Khan, H.K., Chakravarthy, A.K., Ashok Kumar, C.T. and Venkataravana, P. (2014). Biochemical constituents influencing thrips resistance in groundnut germplasam. Journal of Environmental Biology. 35: 675-681. 
Maitra, S., Ghosh, D.C., Sounda, G., Jana, P.K. and Roy, D.K. (2000). Productivity, competition and economics of intercropping legumes in finger millet (Eleusine coracana) at varying fertility level. Indian Journal Agricultural Science. 70(12): 824-828.

Maitra, S., Ghosh, D.C., Sounda, G. and Jana, P.K. (2001). Productivity, competition and economics of intercropping legumes in finger millet (Eleusine coracana) at varying fertility level. Indian Journal of Agronomy. 46(1): 38-44.

McGilchrist, I.A. (1965). Analysis of competition experiments. Biometrics. 21: 975-995.

Odisha Agriculture Statistics (2015-16). Directorate of Agriculture and Food Production, Government of Odisha.

Senaratne, R. and Gunasekara, M.T.K. (1994). Nitrogen fixation, growth and yield of intercropped mungbean (Vigna radiate L.) and groundnut (Arachis hypogaea L.) as affected by the genotype. Journal of Agronomy and Crop Science. 173: 53-60.

Shalim Uddin, M., Rahman M.J., Begum, S.A. and Ali, M.R. (2003). Intercropping of maize with Soybean in saline area under rainfed condition. Bangladesh Journal of Agricultural Research. 28(3): 451-455.

Shiva Kumar, B.G. and Yadahalli, Y.H. (1996). Performance of finger millet genotypes under late sown dryland conditions as influenced by intercrops and intercropping systems. Indian Journal of Agricultural Research. 4: 46-64.
Shwethanjali, K.V., Kumar naik, A.H., Basavarajnaik, T. and Dinesh Kumar, M. (2018). Effect of groundnut based millets intercropping system on growth and yield of groundnut (Arachis hypogaea L.) under rainfed condition. International Journal of Agriculture Sciences. 10(17): 7033-7034.

Shwethanjali, K.V., Kumar naik, A.H., Basavarajnaik, T. and Dinesh Kumar, M. (2018). Effect of groundnut + millets intercropping system on yield and economic advantage in central dry zone of Karnataka under rainfed condition. International Journal of Current Microbiology and Applied Science. 7(9): 2921-2926.

Willey, R.W. (1979). Intercropping its importance and research needs. Part I. Competition and yield advantage. Field Crops Abstract. 32: 1-10.

Willey, R.W. and Rao, M.R. (1980). A competitive ratio for quantifying competition between intercrops. Exp. Agric. 16: 117-125.

Willey, R.W., Reddy, M.S. (1981). A field technique for separating above- and below-ground interaction in intercropping: An experiment with groundnut/groundnut intercropping. Experimental Agriculture. 17: 257-264. 